\title{
Antimalarial Activity of Hydromethanolic Crude Extract and Chloroform Fraction of Brucea antidysenterica Leaves in Plasmodium berghei-Infected Mice
}

\author{
Tezera Jemere Aragaw (iD) and Kefyalew Ayalew Getahun \\ Department of Pharmacology, College of Medicine and Health Sciences, University of Gondar, Gondar, Ethiopia \\ Correspondence should be addressed to Tezera Jemere Aragaw; tezeraadis1982@gmail.com
}

Received 28 July 2021; Revised 14 September 2021; Accepted 22 September 2021; Published 13 October 2021

Academic Editor: Abdul Sadiq

Copyright (c) 2021 Tezera Jemere Aragaw and Kefyalew Ayalew Getahun. This is an open access article distributed under the Creative Commons Attribution License, which permits unrestricted use, distribution, and reproduction in any medium, provided the original work is properly cited.

\begin{abstract}
Background. Different parts of Brucea antidysenterica are used in traditional and alternative medicine in Ethiopia for the treatment of different health problems including malaria and have good in vitro antimalarial activity. However, no in vivo study was conducted to substantiate the claim. Our study planned to determine the antimalarial effect of $B$. antidysenterica extract. Methods. Swiss albino mice (6-8 weeks old, 20-28 g) were inoculated with Plasmodium berghei. Different doses of both hydromethanolic extract and chloroform fraction were orally given at 100,200, and $400 \mathrm{mg} / \mathrm{kg} / \mathrm{day}$. Results. The parasitemia suppression percent of hydromethanolic crude extract and chloroform fraction in chemosuppressive tests ranged between 33.48 and $75.93 \%$ and 38.32 and $76.64 \%$, respectively. The hydromethanolic crude extract and chloroform fraction exhibited the curative effect of $46.75-70.91 \%$ and $50.30-80.06 \%$ parasitemia suppression, respectively $(p<0.001)$, compared with negative control. Conclusion. From our study, it is concluded that the hydromethanolic crude extract and chloroform fraction of B. antidysenterica leaves showed promising antiplasmodial effects against Plasmodium berghei. This upholds the folkloric use of $B$. antidysenterica leaves and the thought of as a possible source to develop new antimalarial agents.
\end{abstract}

\section{Background}

There were approximately 3.3 billion people globally in danger of malaria and 219 million malaria cases and 435,000 deaths worldwide in 2017, and the quantity of cases and burdens increased in Africa [1]. Approximately 125 million pregnant women in 2017 were in danger of infection [2]. 200 thousand yearly infant deaths are caused by Plasmodium falciparum resistance to chloroquine and sulfadoxine-pyrimethamine [3]. In Africa, children below five years old who have at least six malaria-associated illnesses annually are chronic victims. After they are fatally afflicted, children who develop severe symptoms often die within 72 hours. Malaria parasites that drain vital nutrients and impair physical and intellectual development are the principal reasons for poor school attendance of youngsters who survive [4]. In Ethiopia, $75 \%$ of the land below 2000 meters is malarious with $68 \%$ people in danger from infection, with a mean of 5 million cases a year with increased health service expenses and low productivity [5]. In Ethiopia, malaria is among the ten top leading causes of outpatient visit, hospital admission, morbidity, and mortality in children under the age of 5 and adults [6]. Plasmodium falciparum resistance to chloroquine and sulfadoxine/pyrimethamine has been an enormous setback in the fight against malaria [7]. In Ethiopia, $80 \%$ of the people and $90 \%$ of livestock traditional medicines served as an option as modern services are either limited or unavailable [8]. For in vivo evaluation of antimalarial compounds, animal models such as primates, avians, and rodents are used [9]. The choice depends upon the breadth of the response, practical consideration, sensitivity, reproducibility, technical complexity, the quantity of the test compound needed, and price per test, even though this model is not entirely extrapolating the results to humans [10]. 
Among the extensively used animal models of malaria, mice are ideal for in vivo tests. They are small (20-30 g), friendly, and easy to manipulate [11]. Extracts that show an adequate or above $50 \%$ malarial in vivo parasitemia suppression at doses of 500, 250, and $100 \mathrm{mg} / \mathrm{kg} / \mathrm{day}$ are often categorized as moderate, good, and excellent, respectively [12].

In vivo antimalarial screening results of percent parasitemia inhibition of hydromethanolic extracts of various traditionally used plants and their parts in a four-day suppressive test were as follows: $100-400 \mathrm{mg} / \mathrm{kg} /$ day extract dose of Annona senegalensis leaves (57.1-76.3\%) [13], Aloe debrana leaves (30.21-44.15\%), Dodonaea angustifolia leaves (57.74-71.51\%), Clerodendrum myricoides leaves (54.14-65.95\%) [14], Carica papaya fruit rinds (8.18-18.39\%) and roots (10.31-25.63\%) [15], Gardenia ternifolia root bark (32.58-47.02\%) [16], Croton macrostachyus leaves (44-78\%) [17], Sphenocentrum jollyanum leaves (74.75\% at $200 \mathrm{mg} / \mathrm{kg} /$ day) [18], Justicia schimperiana leaves (64.98-81.49\%) [19], Strychnos mitis leaves $(36.56 \%$ at $200 \mathrm{mg} / \mathrm{kg}$ day) [20], Piper betle leaves (52.94-82.31\%) [21], Croton zambesicus leaves (70.7-80.7\%) [22], and Napoleona imperialis roots (96.88-99.1\%) [23].

Brucea antidysenterica is a monoecious shrub up to 7-15 meters tall, with alternate, heart-shaped, gray or brown color leaf-scars; young stems or twigs have red or brown hairs. Fruits have up to 4 ellipsoid mericarps with one seed per mericarp [24].

Brucea antidysenterica roots, fruits, and bark are accustomed for the treatment of fever, helminthic infections, and dysentery. The boiled roots, leaves, seeds, fruits, and bark are accustomed as a remedy for indigestion, stomachache, and diarrhea. To relieve asthma, the roots and leaves are cooked with meat and used. The twigs and leaves are prepared with butter or fruit (ripe) with honey to treat leprosy and scrofula. Cancerous skin tumors and sexually transmitted diseases are treated with leaves and roots, respectively. The colic and bloating in cattle are relieved by powdered leaves. B. antidysenterica root extracts are used to treat rabies and also used as fire wood, leaves serve as animal feed, and the wood is used for house construction [25-27].

The antimalarial activity of an extract showing an IC50 value of $\leq 5 \mu \mathrm{g} / \mathrm{ml}$ was classified as high, whereas extracts with $\mathrm{IC}_{50}$ values between $5 \mu \mathrm{g} / \mathrm{ml}$ and $10 \mu \mathrm{g} / \mathrm{ml}, 10 \mu \mathrm{g} / \mathrm{ml}$ and $50 \mu \mathrm{g} / \mathrm{ml}$, and above $50 \mu \mathrm{g} / \mathrm{ml}$ were considered moderate, low, and inactive, respectively [28]. The activity of bruceantin obtained from the leaves and stem bark of $B$. antidysenterica induces apoptosis involving the caspase and mitochondrial pathways of myeloma cell lines, lymphoma, and leukemia [29, 30].

Bruceantin and simalikalactone D, obtained from B. antidysenterica, showed $\mathrm{IC}_{50}$ values of 0.0008 and $0.0009 \mu \mathrm{g} / \mathrm{ml}$ against Plasmodium falciparum and $\left(\mathrm{IC}_{50}\right.$ of bruceantin $=0.018 \mu \mathrm{g} / \mathrm{ml}$ ) Entamoeba histolytica $[31,32]$.

The hydromethanolic crude extract obtained from B. antidysenterica leaves showed a high in vitro activity, which helps carry on in vivo study to determine whether the hydromethanolic crude extract and chloroform fraction have antimalarial activities using different parameters. From the in vivo antimalarial study, extracts up to a dose of $1000 \mathrm{mg} / \mathrm{kg}$ exhibited greater than or equal to $30 \%$ parasitemia suppression compared with the negative control and hence are considered active [33].

1.1. Rationale of the Study. Emergence of resistance of Plasmodium falciparum to chloroquine and sulfadoxinepyrimethamine causes morbidity and mortality in all segments of the population and is related to enormous setback in the fight against malaria [4-7]. So, there is a desire to possess a new effective agent. Ethnobotanical studies of $B$. antidysenterica showed that its roots, fruits, and bark are accustomed for the treatment of fever, helminthic infections, and dysentery. The boiled roots, leaves, seeds, fruits, and bark are accustomed as a remedy for indigestion, stomachache, and diarrhea. To alleviate asthma, the roots and leaves are cooked with meat and used. The twigs and leaves are prepared with butter or fruit (ripe) with honey to treat leprosy and scrofula. Cancerous skin tumors and sexually transmitted diseases are treated with leaves and roots, respectively. The colic and bloating in cattle are relieved by powdered leaves. Its roots are used to treat rabies and also used as an energy source, and its wood is utilized for house construction [25-27]. The study of secondary metabolites of the hydromethanolic crude extract of $B$. antidysenterica leaves showed a high in vitro antimalarial activity, which helps hold on in vivo study to see whether the hydromethanolic crude extract and chloroform fraction have antimalarial activities [31, 32].

No report is obtainable within the literature suggesting whether the leaves possess in vivo antimalarial activity. This study was therefore planned to evaluate the hydromethanolic crude extract and chloroform fraction of $B$. antidysenterica leaves for antimalarial activity in $P$. berghei-infected mice and additionally acute oral toxicity in the Ethiopian folk medicine.

\section{Materials and Methods}

2.1. Drugs, Chemicals, Supplies, and Equipment. Chloroquine phosphate (CADILA Pharmaceuticals PLC, Ethiopia), absolute methanol (LOBA Chem. Ltd, India), ammonia (Blulux Laboratories (P) Ltd, India), benzene and chloroform (SDFCL Fine Chem. Ltd, India), concentrated sulfuric acid (HiMedia Laboratories Pvt. Ltd, India), distilled water, emersion oil, and absolute ethyl alcohol (GMC Chemical Manufacturing, Ethiopia), ferric chloride and Giemsa stain (AppliChem, Germany), glacial acetic acid, n-hexane, and sodium chloride $0.9 \%$ IV infusion (Sansheng Pharma, Ethiopia), trisodium citrate (3.8\%), Wagner's and Mayer's reagent, aluminum foil, disposable glove (medium size), Gauze 40 mesh, and heparinized syringes with needle of 5/10 ml (Jiangsu Kanghua Medical Equipment Co. Ltd, China), insulin syringes $1 \mathrm{ml}$ (Changzhou Jinlong Medical Plastic Appliance Co. Ltd, China), microscopic slide frosted $(1 \mathrm{~mm}-1.2 \mathrm{~mm}$ thick and $25.4 \mathrm{~mm} \times 76.2 \mathrm{~mm})$, Whatman filter paper $(15 \mathrm{~cm}$ diameter and $0.1 \mu \mathrm{m}$ pore diameter), beakers, lyophilizer, dry oven $(250 \pm 10 \%$ volts AC, 
600 watts, $50 / 60 \mathrm{~Hz}$ ), electrical balance, funnels, HemoCue 3001 machine, HemoCue cuvette, light microscope, measuring cylinder, mice cage, mice gavage, pasture pipette, separating funnel, and stainless scissor $14 \mathrm{~cm}$ long.

2.2. Plant Material. Brucea antidysenterica fresh leaves were collected on May 13, 2019, from Agew Awi Zone within Amhara Region. It is located at $10^{\circ} 57^{\prime} \mathrm{N}$ and $36^{\circ} 56^{\prime} \mathrm{E}$ in Banja Shekudad District at an elevation of 2560 meters above sea level. The collected leaves were wrapped and covered with plastic sheets during transportation. The specimen of the plant was authenticated as Brucea antidysenterica by a botanist, within the Department of Biology, the University of Gondar, and was deposited within the herbarium with a voucher specimen No: 005/KAG/2020 for future reference.

\subsection{Preparations of Crude Methanolic Extract. Brucea} antidysenterica leaves were dried in shadow and at an ambient temperature, reduced in size by hand compression, and stored at room temperature until the extraction. Brucea antidysenterica leaf powder of $400 \mathrm{~g}$ was weighed with an electrical balance and transferred to a beaker, and $2400 \mathrm{ml}$ of $80 \%$ hydromethanolic solution was added and shaken in between to homogenize. After three days of maceration, extraction was performed using thick layers of 40 mesh gauze and filtered with Whatman paper № 1 twofold, and the $2^{\text {nd }}$ extraction was performed again after three days post maceration; the $3^{\text {rd }}$ extraction was repeated another 72 hours later (an entire of nine days). The filtrates were combined and were frozen overnight using a deep freezer and freezedried in a lyophilizer at $-50^{\circ} \mathrm{C}$ to eliminate water. The yield was measured and calculated to be $42.6 \mathrm{~g}(10.65 \%)$ and stored in a refrigerator at $4^{\circ} \mathrm{C}$ until use $[34,35]$.

\subsection{Solvent Fractionation of Crude Extract.} Hydromethanolic crude extract of $B$. antidysenterica leaves was processed for further fractionation using polar and nonpolar solvents with increasing polarity n-hexane $(0.1)$, chloroform (4.1), and water (10.2). Dried hydromethanolic crude extract of $B$. antidysenterica leaves of $70 \mathrm{gm}$ was weighed and soaked in $420 \mathrm{ml}$ distilled water and was gently shaken to combine. The mixture was transferred to a separatory funnel. Then, equal volume of n-hexane was added to it. After being gently shaken, the extract was allowed to settle and separated into two distinct layers consistent with their density. The upper n-hexane layer was collected, and then the same procedure was repeated 3 times. After the gathering of $n$-hexane fraction of the extract, the water was fractionated with chloroform 3 times with same procedure of n-hexane and also the bottom chloroform layer was collected, leaving the upper aqueous fraction. Finally, the aqueous fraction was collected. The filtrates of chloroform and $n$-hexane fractions were concentrated using a rotary evaporator and dried using a dry oven at $40^{\circ} \mathrm{C}$. The aqueous fraction was frozen in a refrigerator overnight and was dried using a lyophilizer. The percentage yield was calculated, and the yield was stored at $4^{\circ} \mathrm{C}$ until use [36].
2.5. Phytochemical Screening. The qualitative phytochemical screening tests of secondary metabolites were performed on $80 \%$ hydromethanolic crude extract of Brucea antidysenterica leaves using standard chemicals and procedures that were utilized in previous research [37-47].

2.6. Animals and Parasite. We purchased mice (Swiss albino) aged 6-8 weeks weighing 20-28 g, either sex, from the Ethiopian Public Health Institute (EPHI), Addis Ababa. The mice were kept (five to 6 mice/cage) in clean polyethylene plastic cages with a wire mesh top containing a hygienic bed in fact sawdust (regularly changed every 3 days) and retained in a well-ventilated room $24-25^{\circ} \mathrm{C}, 50-60 \%$ humidity, and a light-dark cycle of 12 hours with free delivery of ordinary pellet diet purchased from local suppliers and clean potable tap water. Then, the mice were acclimatized with the test environment for seven days before the initiation of the experiment. The care and handling of mice were performed with globally accepted standard laboratory protocols and guidelines [35, 48, 49]. The research was performed as per the agreement of the ethical clearance document Ref. No: DU/RPD/102/2015.

Chloroquine-sensitive Plasmodium berghei was obtained from the Traditional Medicine Research Department, EPHI, in Addis Ababa and transported by infecting the donor mice and maintained the parasite until the actual procedure of the study.

2.7. Acute Toxicity Test. Five female Swiss albino mice were kept for seven days before dosing to acclimatize to the test environment. One mouse was randomly taken to perform preliminary toxicity observation on free access to potable tap water but fasted for four hours and weighed, and then hydromethanolic crude extract of $2 \mathrm{~g} / \mathrm{kg}$ leaves of B. antidysenterica was administered via the oral route. Firm inspection was done for half an hour and periodically for the primary 24 hours, for consecutive fourteen days. Observation was majorly focused on changes in skin and fur, eyes, mucous membranes, respiratory, circulatory, autonomic, and central nervous system, and somatomotor activity and behavior patterns were observed. Tremors, convulsions, salivation, diarrhea, lethargy, sleep, and coma were evaluated. The mouse did not show any sign of toxicity for four days in initial toxicity inspection. The remaining four Swiss albino female mice were dosed by similar doses and followed up for 14 days $[35,48,50]$.

2.8. Pharmacologic Screening (4-Day Suppressive Test). The evaluation of crude hydromethanolic extracts and chloroform fraction of $B$. antidysenterica leaves for in vivo antimalarial activity on rodent protozoan $P$. berghei was performed. Donor $P$. berghei-infected Swiss albino mice (parasitemia of roughly 30\%) were sacrificed by decapitation; then blood was drawn from the heart by cardiac puncture with a disposable sterile syringe and needle. Sterile $0.9 \%$ normal saline and anticoagulant trisodium citrate were used to dilute the blood; $0.2 \mathrm{ml}$ of blood contained about $10^{7}$ 
infected erythrocytes, and the mice were infected by $0.2 \mathrm{ml}$ blood suspension intraperitoneally to cause consistent infection in mice [49]. Randomly divided the mice in groups of eight, six mice in each group, free access to food and water, and weighed. The doses of crude hydromethanolic extract and fraction of chloroform of $B$. antidysenterica leaves were adjusted from the safest dose of acute toxicity study (2000 mg/kg), and the doses were $20 \%$ (400 mg/kg/day), $10 \%$ (200 mg/kg/day), and 5\% (100 mg/kg/day) from higher to lower doses, respectively. Three different doses of hydromethanolic crude extract were administered to the mice for 4 days, and they were grouped accordingly: Group I, $100 \mathrm{mg} /$ kg/day; Group II, 200 mg/kg/day, and Group III, 400 mg/kg/ day; and similarly, mice were grouped according to the chloroform fraction: Group IV, $100 \mathrm{mg} / \mathrm{kg} / \mathrm{day}$, Group V, $200 \mathrm{mg} / \mathrm{kg} /$ day), and Group VI, $400 \mathrm{mg} / \mathrm{kg} /$ day. Group VII received chloroquine base $10 \mathrm{mg} / \mathrm{kg} /$ day (positive control), and Group VIII received a solvent $(10 \mathrm{ml} / \mathrm{kg} /$ day $)$ composed of Tween $80(7 \mathrm{ml})+$ ethanol $96 \%(3 \mathrm{ml})+$ distilled water $(90 \mathrm{ml})$ (negative control) $[17,35,51]$ orally using oral gavage after three hours of parasite inoculation.

2.9. Rane's (Curative) Test. Evaluations of crude hydromethanolic extract and chloroform fraction of $B$. antidysenterica leaves were performed with the strategy described by curative methods [9]. About $10^{7}$ infected erythrocytes were inoculated in mice intraperitoneally on day 0 and randomly divided into eight groups, six mice in each group. Group I (negative control) treated with solvent $10 \mathrm{ml} /$ $\mathrm{kg}$ /day, Group II treated with crude hydromethanolic extract at $100 \mathrm{mg} / \mathrm{kg} /$ day, Group III treated with crude hydromethanolic extract at $200 \mathrm{mg} / \mathrm{kg} /$ day, Group IV treated with crude hydromethanolic extract at $400 \mathrm{mg} / \mathrm{kg} / \mathrm{day}$, Group V treated with chloroform fraction at $100 \mathrm{mg} / \mathrm{kg} /$ day, Group VI treated with chloroform fraction at $200 \mathrm{mg} / \mathrm{kg} /$ day, Group VII treated with chloroform fraction at $400 \mathrm{mg} / \mathrm{kg} / \mathrm{day}$, Group
VIII treated with chloroquine base at $10 \mathrm{mg} / \mathrm{kg} /$ day. Mice were weighed and maintained on a pellet diet. Administration of the crude hydromethanolic extract at 100, 200, and $400 \mathrm{mg} /$ $\mathrm{kg} /$ day, chloroform fraction at 100,200 , and $400 \mathrm{mg} / \mathrm{kg} /$ day, chloroquine base at $10 \mathrm{mg} / \mathrm{kg} / \mathrm{day}$, and a solvent $(10 \mathrm{ml} / \mathrm{kg})$ prepared from Tween $80 \quad(7 \mathrm{ml})+$ ethanol $96 \%$ $(3 \mathrm{ml})+$ distilled water $(90 \mathrm{ml})$ to the respective groups was started on third day and continued once daily for five days. A Giemsa-stained thin blood film was prepared from the tail of each mouse daily for five days (day 3, 4, 5, 6, and 7) to quantify the parasitemia level. The Swiss albino mice were followed up for 30 days and calculated arithmetically to determine the mean survival time for each group starting from the date of infection for 30 days (D0-D29) [17, 35].

2.9.1. Determination of Parasitemia. Starting from infection at 96 hours, a drop of blood was collected from the mice by the vein section of the tail and transferred onto to a microscopic slide and drawn evenly across the second slide to create a thin blood film and allowed to dry at room temperature, fixed with methanol, and stained with $10 \%$ Giemsa stain for half an hour. Slides were viewed using light microscopy with oil immersion (1000x magnification). Parasite load in percent was determined by counting parasitized red blood cells out of $200 \mathrm{RBCs}$ in random fields of the microscope. For each mouse, five fields were examined. Then, parasitemia percent was calculated by the following formula $[17,35]$ :

$$
\% \text { parasitemia }=\frac{\text { total number of } \mathrm{PRBC}}{\text { total number of } \mathrm{RBC}} \times 100,
$$

where PRBC represents the parasitized red blood cells and RBC means red blood cells.

Average percentage of parasitemia suppression was calculated as follows:

$$
\text { average } \% \text { of parasitemia supression }=\frac{\text { avg. } \% \text { of parasitemia in negative control }- \text { avg. } \% \text { of parasitemia in test }}{\text { avg. } \% \text { of parasitemia in negative control }} \times 100,
$$

where Av = average.

2.9.2. Determination of Body Weight. The body weight of the mice was measured to judge whether the test extract of
B. antidysenterica leaves prevented weight loss. The weight was assessed on day 0 (after an infection was initiated) and on day 4 (96 hours) post infection $[35,52]$.

$$
\text { average } \% \text { body weight loss }=\frac{\text { avg. body weight of mice at day } 0-\text { avg. body weight of mice at day } 4(\mathrm{~g})}{\text { avg. body weight of mice at day } 0(\mathrm{~g})} \times 100 \text {. }
$$

2.9.3. Determination of Hemoglobin Level. The hemoglobin level of the mice was measured to judge the effectiveness of hydromethanolic crude extract and chloroform fraction of Brucea antidysenterica leaves in preventing anemia. Hemoglobin was evaluated by using a hemoglobin cuvette and hemoglobin machine. Blood samples were collected from the vein section of mice's tail by a trained medical laboratory technologist with optimum pressure applied on the tail and filled in a microcuvette ( $\mathrm{Hb} 301)$ approximately $10 \mu \mathrm{l}$. Excess blood was removed before inserting the microcuvette into 
the machine. Then, hemoglobin levels in $\mathrm{g} / \mathrm{dl}$ were displayed automatically, and the mean hemoglobin level was determined using the following formula $[35,53]$ :

$$
\text { mean hemoglobin }=\frac{\text { sum of hemoglobin for all mice in a group }(\text { in } \mathrm{g} / \mathrm{dl})}{\text { total number of mice in that group }} \text {. }
$$

2.9.4. Determination of Mean Survival Time. The Swiss albino mice were maintained with free delivery of ordinary pellet diet purchased from local suppliers and clean potable tap water. For 28 days, the mice were observed and deaths were recorded to judge the crude hydromethanolic extract and chloroform fraction effect for improvement in survival days [9].

$$
\text { Mean survival times }=\frac{\text { Sum of survival times for all mice a group }(\text { in days })}{\text { Total number of mice in that group }} .
$$

2.9.5. Data Analysis. The results of the study were expressed as mean \pm standard error of the mean $(M \pm S E M)$. Parasitemia comparison and statistical significance were resolved by one-way ANOVA descriptive statistics. Post hoc tests for multiple comparisons of Tukey's HSD and paired $t$-tests were employed to check significance for the difference between initial and final results within and between identical groups using SPSS for Windows (version 20.0) IBM statistical package. All data were analyzed at a 95\% confidence interval, and $p<0.05$ was considered statistically significant [54].

\section{Results}

3.1. Phytochemical Screening. The evaluation of phytoconstituents of crude hydromethanolic extract of $B$. antidysenterica leaves indicated existence of sterols, alkaloids, phenols, flavonoids, saponins, terpenoids, and tannins, but alkaloids were only present in chloroform fraction of $B$. antidysenterica leaves (see Table 1).

3.2. Evaluation of Acute Oral Toxicity. The evaluation of acute oral toxicity did not show any physical or behavioral changes or deaths up to 14 days from the administration of crude hydromethanolic extract at $2 \mathrm{~g} / \mathrm{kg}$.

3.3. Antimalarial Suppressive Test. The antimalarial suppression evaluation of crude hydromethanolic extract and chloroform fraction of $B$. antidysenterica leaves in $P$. bergheiinfected mice showed a lower parasite level compared with their respective solvent-treated mice. The parasite was totally cleared in mice treated with chloroquine base $10 \mathrm{mg} / \mathrm{kg}$. The crude hydromethanolic extract of $B$. antidysenterica leaves at 100,200 , and $400 \mathrm{mg} / \mathrm{kg} /$ day showed 33.48, 58.36, and $75.93 \%$ parasitemia suppression, respectively, whereas the chloroform fraction of $B$. antidysenterica leaves at 100, 200, and $400 \mathrm{mg} / \mathrm{kg} /$ day showed $38.32,64.49$, and $76.64 \%$ parasitemia suppression, respectively; therefore, the differences in the results were highly significant $(p<0.001)$ when compared with solvent-treated mice at day 4 (see Table 2).

3.4. Effects of Crude Hydromethanolic Extract and Chloroform Fraction of B. antidysenterica Leaves on Body Weight in $P$. berghei-Infected Mice. $P$. berghei-infected mice treated with crude hydromethanolic extract of $B$. antidysenterica leaves at $100 \mathrm{mg} / \mathrm{kg}$ lost $9.34 \pm 1.61 \%(p=0.770)$ of weight, $200 \mathrm{mg} / \mathrm{kg} 6.49 \pm 1.19 \%(p=0.844)$ of weight, and $400 \mathrm{mg} /$ $\mathrm{kg} /$ day $1.78 \pm 0.98 \% \quad(p<0.001)$ of weight. Chloroform fraction of $B$. antidysenterica leaves at $100 \mathrm{mg} / \mathrm{kg}$ lost $9.24 \pm 1.62 \%(p=0.741)$ of weight, $200 \mathrm{mg} / \mathrm{kg} 5.43 \pm 0.95 \%$ $(p=0.023)$ of weight, and $400 \mathrm{mg} / \mathrm{kg} / \mathrm{day} \quad 0.18 \pm 0.76 \%$ $(p<0.001)$ of weight. Chloroquine base at $10 \mathrm{mg} / \mathrm{kg} / \mathrm{day}$ gained $4.10 \pm 1.23 \%(p<0.001)$ of weight and mice treated with solvent lost $12.49 \pm 2.38 \%$ of weight (see Figure 1).

3.5. Activity of Crude Hydromethanolic Extracts and Chloroform Fraction of $B$. antidysenterica Leaves on Average Hemoglobin Level of $P$. bergei-Infected Mice. The average hemoglobin level after administration of crude hydromethanolic extract of $B$. antidysenterica leaves at $100 \mathrm{mg} / \mathrm{kg} /$ day was $\quad 8.07 \pm 0.23 \mathrm{~g} / \mathrm{dl} \quad(p=0.251), \quad 200 \mathrm{mg} / \mathrm{kg} / \mathrm{day}$ $9.87 \pm 0.40 \mathrm{~g} / \mathrm{dl} \quad(p<0.001), \quad$ and $\quad 400 \mathrm{mg} / \mathrm{kg} / \mathrm{day}$ $12.95 \pm 0.54 \mathrm{~g} / \mathrm{dl} \quad(p<0.001)$; for chloroform fraction at $100 \mathrm{mg} / \mathrm{kg} /$ day was $9.38 \pm 0.30 \mathrm{~g} / \mathrm{dl}(p<0.001), 200 \mathrm{mg} / \mathrm{kg} /$ day $11.75 \pm 0.32 \mathrm{~g} / \mathrm{dl} \quad(p<0.001)$, and $400 \mathrm{mg} / \mathrm{kg} / \mathrm{day}$ $13.52 \pm 0.38 \mathrm{~g} / \mathrm{dl}(p<0.001)$; for chloroquine base at $10 \mathrm{mg} /$ $\mathrm{kg} /$ day was $14.15 \pm 0.32 \mathrm{~g} / \mathrm{dl}(p<0.001)$; and for noninfected mice was $14.37 \pm 0.24 \mathrm{~g} / \mathrm{dl}(p<0.001)$ compared with the negative control $(6.55 \pm 0.68)$ (see Figure 2 ).

3.6. Effects of Crude Hydromethanolic Extract and Chloroform Fraction of B. antidysenterica Leaves on Mean Survival Time of P. bergei-Infected Mice in a 4-Day Suppressive Test. Hydromethanolic crude extract of $B$. antidysenterica leaves at 100,200 , and $400 \mathrm{mg} / \mathrm{kg} /$ day showed mean survival time 
TABle 1: Preliminary phytochemical screening of hydromethanolic crude extract and chloroform fraction of B. antidysenterica leaves.

\begin{tabular}{|c|c|c|c|}
\hline Phytoconstituents & Type of test & Appearance when positive & Result \\
\hline Alkaloids & Wagner's and Mayer's tests & $\begin{array}{c}\text { Reddish brown and white creamy } \\
\text { ppt. }\end{array}$ & + \\
\hline Anthraquinones & Borntrager's test (chloroform $+\mathrm{NaOH}$ ) & Red color & - \\
\hline Cardiac glycosides & $\begin{array}{l}\text { Keller-Kiliani test (glacial acetic acid }+ \text { ferric chloride }+ \text { concentrated } \\
\text { sulfuric acid) }\end{array}$ & A brown ring & - \\
\hline Flavonoids & Alkaline reagent test & Colorless & + \\
\hline $\begin{array}{l}\text { Phenolic } \\
\text { compounds }\end{array}$ & Ferric chloride & Bluish black & + \\
\hline Resins & Ethanol + distilled water & Formation of a ppt. & - \\
\hline Saponins & Foam test & Foam & + \\
\hline Sterols & Liebermann-Burchard test (chloroform + acetic acid + sulfuric acid) & Blue green ring & + \\
\hline Tannins & Ferric chloride & $\begin{array}{l}\text { A brownish green or blue black } \\
\text { coloration }\end{array}$ & + \\
\hline Terpenoids & Salkowski's test (sulfuric acid + chloroform) & Reddish brown & + \\
\hline
\end{tabular}

+ indicates presence; - indicates absence; ppt.: precipitate.

TABLE 2: Effects of crude hydromethanolic extract and chloroform fraction of B. antidysenterica leaves on P. berghei-infected mice in a 4-day suppressive test.

\begin{tabular}{lcc}
\hline Extract & Percent parasitemia & Percent parasitemia inhibition \\
\hline $\mathrm{CON}_{10 \mathrm{ml} / \mathrm{kg}}$ & $42.8 \pm 1.70$ & 0.00 \\
$\mathrm{CM}_{100 \mathrm{mg} \cdot \mathrm{kg}}$ & $28.47 \pm 0.41^{\mathrm{acde}(3)}$ & 33.48 \\
$\mathrm{CM}_{200 \mathrm{mg} / \mathrm{kg}}$ & $17.82 \pm 0.39^{\mathrm{abde}(3)}$ & 58.36 \\
$\mathrm{CM}_{400 \mathrm{mg} / \mathrm{kg}}$ & $10.3 \pm 0.32^{\mathrm{abce}(3)}$ & 75.93 \\
$\mathrm{CF}_{100 \mathrm{mg} / \mathrm{kg}}$ & $26.4 \pm 0.30^{\mathrm{acde}(3)}$ & 38.32 \\
$\mathrm{CF}_{200 \mathrm{mg} / \mathrm{kg}}$ & $15.2 \pm 0.73^{\mathrm{abde}(3)}$ & 64.49 \\
$\mathrm{CF}_{400 \mathrm{mg} / \mathrm{kg}}$ & $10.00 \pm 0.21^{\mathrm{abce}(3)}$ & 76.64 \\
$\mathrm{CQ}_{10 \mathrm{mg} / \mathrm{kg}}$ & $0.00 \pm 0.00^{\mathrm{abcd}(3)}$ & 100.00 \\
\hline
\end{tabular}

Data are expressed as mean $\pm \mathrm{SEM} ; n=6$; $\mathrm{CON}=$ control; $\mathrm{CM}=$ crude hydromethanolic extract; $\mathrm{CF}=$ chloroform fraction of Brucea antidysenterica; $\mathrm{CQ}=$ chloroquine. a, compared with negative control; b, compared with $100 \mathrm{mg} / \mathrm{kg}$; c, compared with $200 \mathrm{mg} / \mathrm{kg}$; d, compared with $400 \mathrm{mg} / \mathrm{kg}$; e, compared with $\mathrm{CQ}_{10 \mathrm{mg} / \mathrm{kg}}: 3=p<0.001$.

of $6.5 \pm 0.43$ days $(p=0.849), 7.67 \pm 0.42$ days $(p=0.0 .218)$ and $12.67 \pm 0.76$ days $(p<0.001)$, and chloroquine base at $10 \mathrm{mg} / \mathrm{kg} /$ day showed $23 \pm 1.18(p<0.001)$ days, respectively. Chloroform fraction of $B$. antidysenterica leaves at $100,200,400 \mathrm{mg} / \mathrm{kg} /$ day showed $7.9 \pm 0.36 \quad(p=0.070)$, $9.45 \pm 0.33(p=0.001)$, and $14.67 \pm 0.33$ days $(p<0.001)$ of mean survival time, and chloroquine base at $10 \mathrm{mg} / \mathrm{kg} / \mathrm{day}$ showed $23 \pm 1.18(p<0.001)$ days, respectively, and the mice treated with solvent showed $5.5 \pm 0.34$ days (see Figure 3 ).

3.7. Antimalarial Curative Test. The antimalarial curative test of hydromethanolic crude extract of $B$. antidysenterica leaves at 100, $200(62.11 \%)$, and $400 \mathrm{mg} / \mathrm{kg}$ showed $46.75 \%$, $62.11 \%$, and $70.91 \%$ parasitemia inhibition, respectively; chloroform fraction at 100,200 , and $400 \mathrm{mg} / \mathrm{kg}$ showed $50.3 \%, 65.5 \%$, and $80.06 \%$ parasitemia inhibition, respectively; and chloroquine base at $10 \mathrm{mg} / \mathrm{kg}$ showed $93.13 \%$ parasitemia inhibition in $P$. berghei-infected mice at day 5; therefore, the differences in the results were highly significant $(p<0.001)$ when compared with the negative control (see Table 3).

The hydromethanolic crude extract of $B$. antidysenterica leaves at 100,200 , and $400 \mathrm{mg} / \mathrm{kg}$ exhibited $7.50 \pm 0.43$, $9.33 \pm 0.33$, and $12.17 \pm 0.60$ days of mean survival time, respectively; chloroform fraction of $B$. antidysenterica leaves at 100,200 , and $400 \mathrm{mg} / \mathrm{kg}$ showed $9.50 \pm 0.43$, $12.33 \pm 0.42$ days, and $15.33 \pm 0.76$ days of mean survival time, respectively; and chloroquine base at $10 \mathrm{mg} / \mathrm{kg} / \mathrm{day}$ showed a mean survival time of $30.00 \pm 0.00$ days in the curative test; therefore, the differences in the results were highly significant $(p<0.001)$ when compared with negative control (5.33 \pm 0.21 days) (see Table 3$)$.

3.8. Effects of Crude Hydromethanolic Extract and Chloroform Fraction of B. antidysenterica Leaves on Mean Survival Time of Mice Infected with $P$. bergei in a Curative Test. Hydromethanolic crude extract of $B$. antidysenterica leaves at 100,200 , and $400 \mathrm{mg} / \mathrm{kg} /$ day showed $7.50 \pm 0.43$ $(p=0.003), \quad 9.33 \pm 0.33 \quad(p<0.001), \quad$ and $\quad 12.17 \pm 0.60$ $(p<0.001)$, respectively, and chloroquine base at $10 \mathrm{mg} / \mathrm{kg} /$ day showed $30.00 \pm 0.00(p<0.001)$ days of mean survival time in a curative test. Chloroform fraction of $B$. antidysenterica leaves at 100,200 , and $400 \mathrm{mg} / \mathrm{kg} / \mathrm{day}$ showed $9.50 \pm 0.43(p=0.070), 12.33 \pm 0.42(p=0.001)$, and $15.33 \pm 0.76(p<0.001)$, respectively, and chloroquine base at $10 \mathrm{mg} / \mathrm{kg} /$ day showed $30.00 \pm 0.00(p<0.001)$ days of mean survival time in a curative test; and mice treated with solvent showed $5.33 \pm 0.21$ days (see Figure 4). 


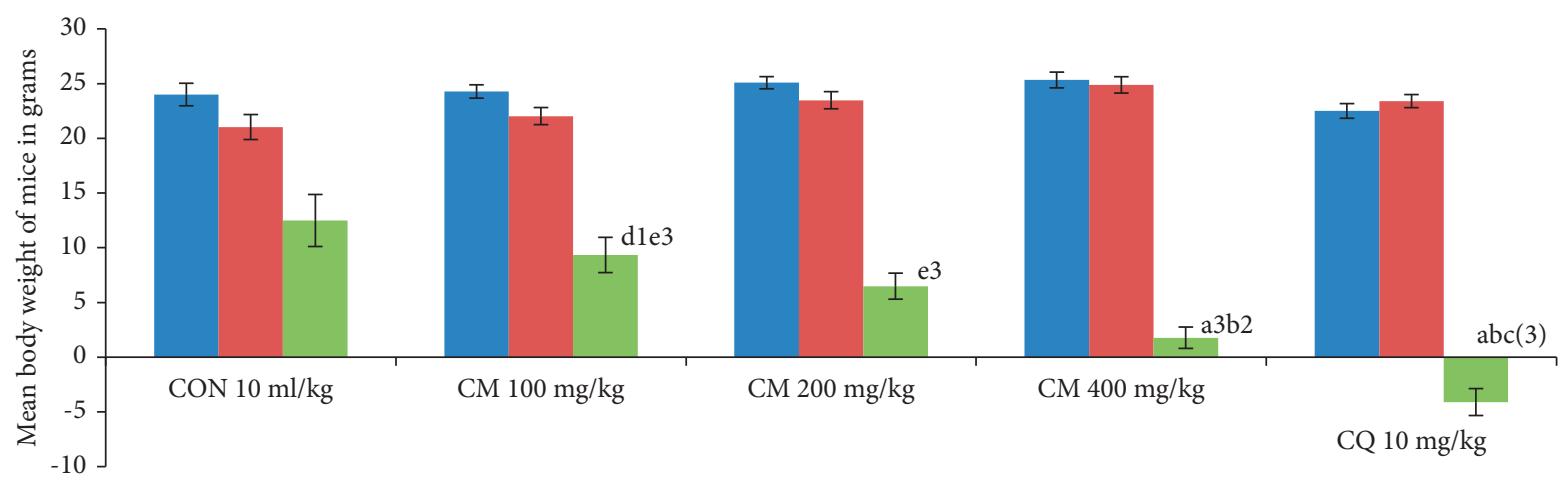

Treatment group

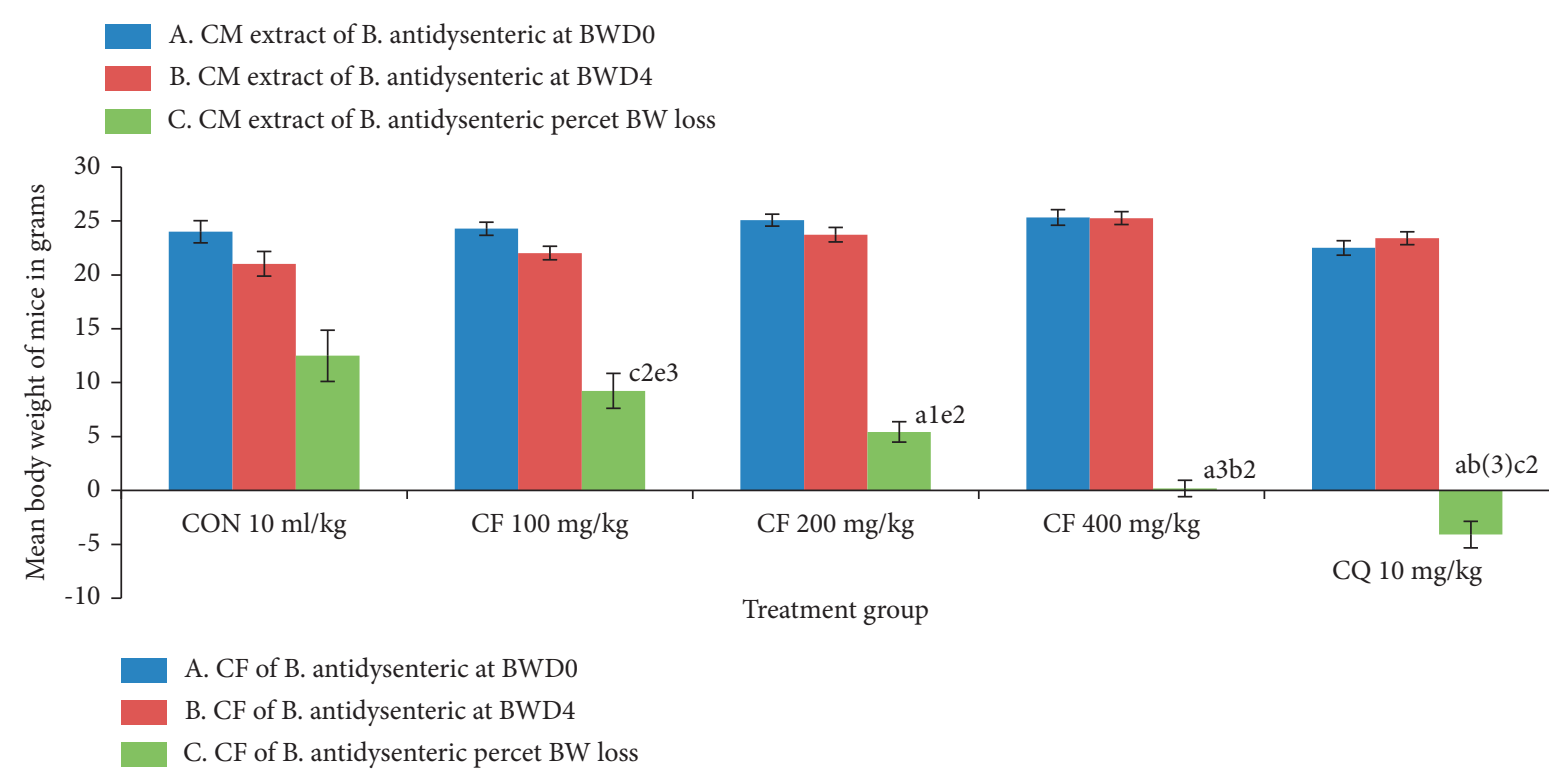

FIGURE 1: Effects of crude hydromethanolic extract and chloroform fraction of B. antidysenterica on body weight of $P$. berghei-infected mice in a 4-day chemosuppressive test. $N=6, \mathrm{CON}=$ negative control (solvent $10 \mathrm{ml} / \mathrm{kg}$ ), I= standard error of mean, $\mathrm{CM}=$ crude hydromethanolic extract, $\mathrm{CF}=$ chloroform fraction of $\mathrm{CM}, \mathrm{CQ}=$ chloroquine. a, compared with negative control; b, compared with $100 \mathrm{mg} / \mathrm{kg}$; c, compared with $200 \mathrm{mg} / \mathrm{kg} ; \mathrm{d}$, compared with $400 \mathrm{mg} / \mathrm{kg}$; e, compared with CQ10 mg/kg; f, compared with noninfected mice: $2, p<0.01 ; 3, p<0.001$.

\section{Discussion}

Resistance of Plasmodium falciparum to chloroquine and sulfadoxine-pyrimethamine causes morbidity and mortality in all segments of the population and is associated with enormous setback in the fight against malaria [4-7]. There is a need to have a new effective agent. Therefore, we assessed the antimalarial activity of hydromethanolic crude extract and chloroform fraction of $B$. antidysenterica leaves in $P$. berghei-infected mice. Ethnobotanical studies of B. antidysenterica roots, fruits, and bark are accustomed for the treatment of fever, helminthic infections, and dysentery. The boiled roots, leaves, seeds, fruits, and bark are accustomed as a remedy for indigestion, stomachache, and diarrhea. To relieve asthma, the roots and leaves are cooked with meat and used. The twigs and leaves are prepared with butter or fruit (ripe) with honey to treat leprosy and scrofula. Cancerous skin tumors and sexually transmitted diseases are treated with leaves and roots, respectively. The colic and bloating in cattle are relieved by powdered leaves. Its roots are used to treat rabies and also used as an energy source, and the wood is used for house construction [25-27]. The study of secondary metabolites of hydromethanolic crude extract of $B$. antidysenterica leaves showed a high in vitro activity, which helps carry on in vivo study to determine whether the hydromethanolic crude extract and chloroform fraction have antimalarial activities [31, 32]. B. antidysenterica contains considerable constituents of secondary bioactive constituents such as alkaloids, flavonoids, phenols, saponins, sterols, tannins, and terpenoids. The antimalarial effects of both hydromethanolic crude extract and chloroform fraction of $B$. antidysenterica leaves have higher mean percent parasitemia inhibition, reduction in weight, prevention of anemia, and a rise in mean survival time in days in a dose-dependent manner, which may be related to these secondary metabolites. Alkaloids have the capacity to DNA intercalation and terminate division of cells [40]. Flavonoids have the potential of complexing with soluble and intracellular proteins of cell components of organisms. Microbial membranes are at risk of being destroyed with flavonoids of high lipophilicity and inactivate toxins and inhibited isolated enzymes and complexing 


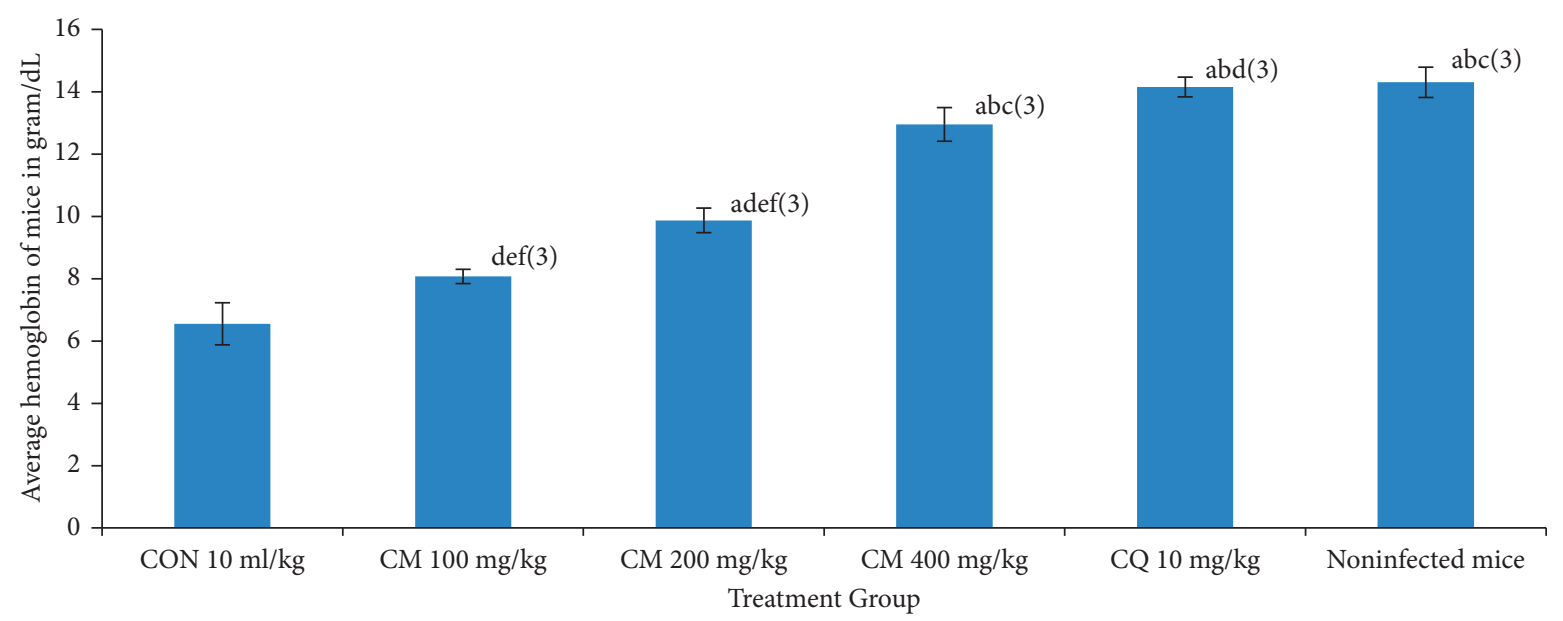

A. CM extract of B. antidysenterica leaves in hemoglobin level in $\mathrm{g} / \mathrm{dL}$

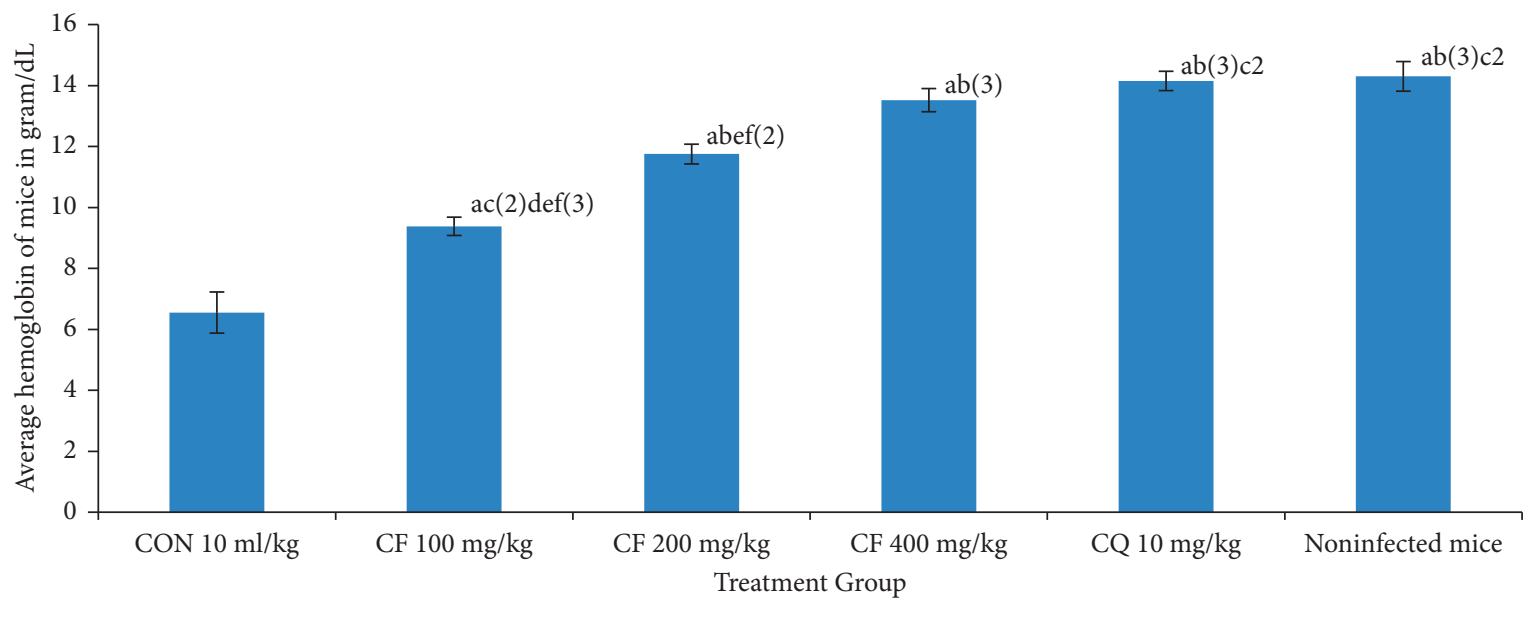

A. CF of B. antidysenterica leaves in hemoglobin level in $\mathrm{g} / \mathrm{dL}$

FIGURE 2: Effects of crude methanolic extract and chloroform fraction of B. antidysenterica leaves on mean hemoglobin level of mice infected with $P$. berghei in a 4-day suppressive test. $N=6, \mathrm{CON}=$ negative control (solvent $10 \mathrm{ml} / \mathrm{kg}$ ), $\mathrm{CM}=$ crude hydromethanolic extract, $\mathrm{CF}=$ chloroform fraction of $\mathrm{CM}, \mathrm{CQ}=$ chloroquine. a, compared with negative control; b, compared with $100 \mathrm{mg} / \mathrm{kg}$; $\mathrm{c}$, compared with $200 \mathrm{mg} / \mathrm{kg} ; \mathrm{d}$, compared with $400 \mathrm{mg} / \mathrm{kg}$; e, compared with CQ10 mg/kg; f, compared with noninfected mice: $2, p<0.01 ; 3, p<0.001$.

activities [40, 41]. Phenolic compounds produce inhibition of enzymes on oxidation and sulfhydryl interaction and other nonspecific proteins of microorganisms and produce toxicities [42]. Tannins have the power to initiate covalent, hydrogen, hydrophobic bonding, and complexing hostmediated tumor activity and phagocytosis [40]. The terpenes' mode of activity remains obscured, but compounds with this lipophilic character may disrupt membranes [40, 41]. These secondary metabolites present in $B$. antidysenterica leaves are going to be accustomed as a remedy for various ailments traditionally. Because of the presence of these secondary metabolites, $B$. antidysenterica has high healing potential, which is confirmed by the obtained results of the antimalarial activity.

The crude hydromethanolic extract did not produce toxicity and death at the test dose of the extract during the observation period. B. antidysenterica leaves hydromethanolic extract was nontoxic to tested mice and within the ranges tested during this study. Due to species variation, we cannot apply this finding to humans. Therefore, the crude hydromethanolic extract and chloroform fraction of $B$. antidysenterica leaves were administered in Plasmodium berghei-infected mice, which exhibited a dose-dependent activity in percent parasitemia inhibition. The crude hydromethanolic extract of $B$. antidysenterica leaves on a 4-day suppressive test on mice infected with $P$. berghei at $100 \mathrm{mg} / \mathrm{kg} /$ day showed an average percent parasitemia suppression (33.48\%) higher than Carica papaya fruit rinds (8.18\%) and roots (10.31\%) [15] and less than Annona senegalensis leaves (57.1\%) [13], Justicia schimperiana leaves (64.98\%) and roots (49.51\%) [19], Piper betle leaves (52.94\%) [21], and Croton zambesicus leaves (70.7\%) [22]. The crude hydromethanolic extract of $B$. antidysenterica leaves in an exceedingly 4-day suppressive test on mice infected with $P$. berghei at $200 \mathrm{mg} / \mathrm{kg} /$ day showed an average percent parasitemia suppression (58.36\%) higher than Clerodendrum myricoides leaves (54.14\%), Dodonaea angustifolia leaves 


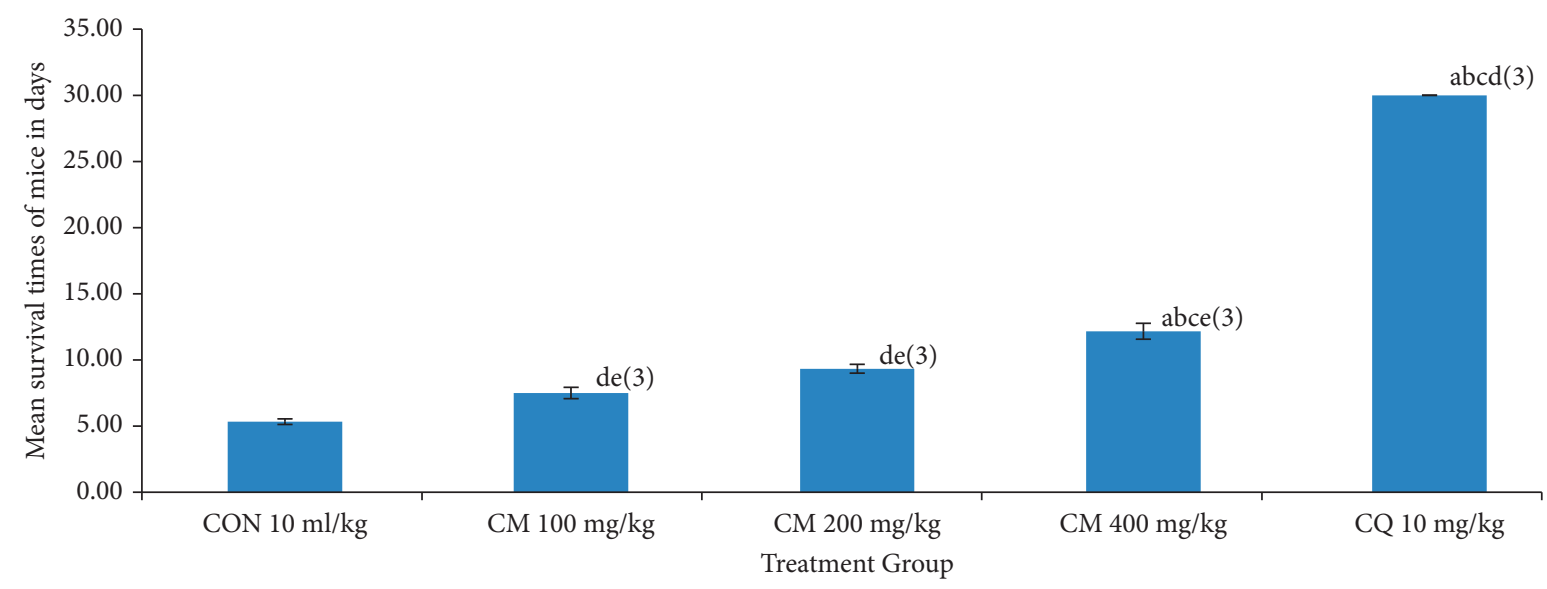

A. CM extract of B. antidysenterica on mean survival of mice in days

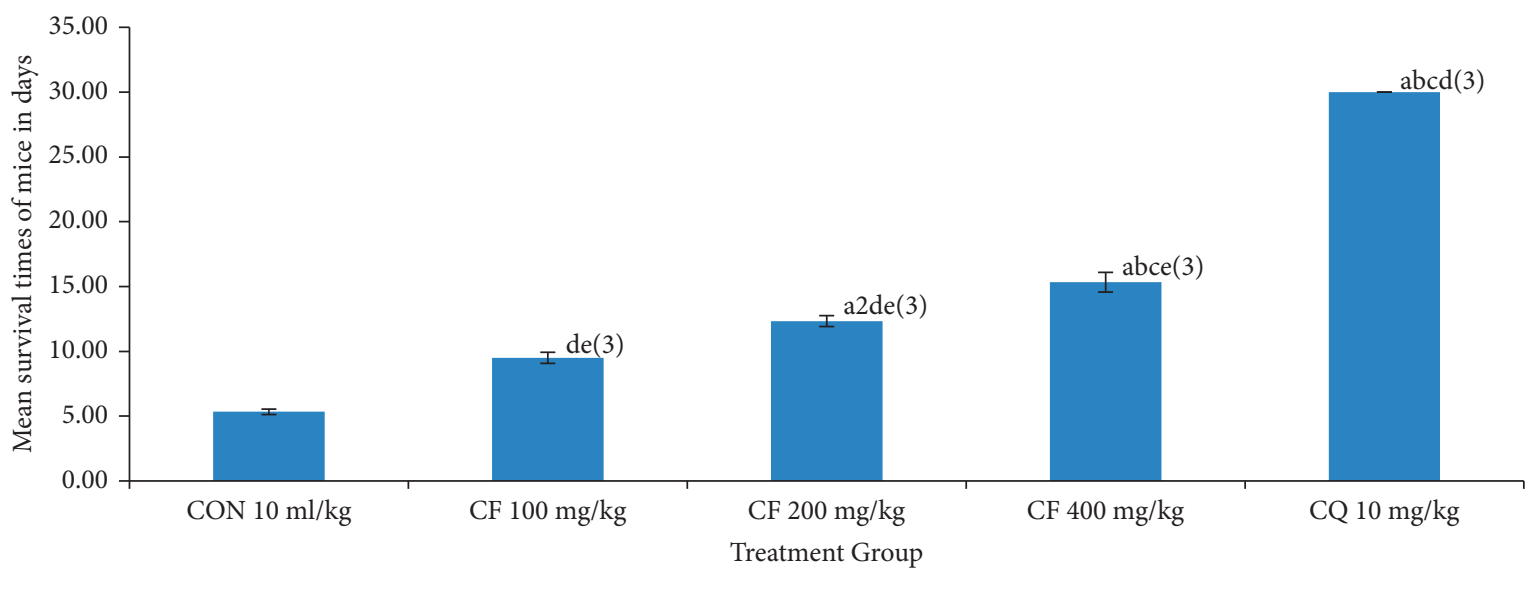

B. CF of B. antidysentericaon mean survival of mice in days

FIGURE 3: Effects of crude hydromethanolic extract and chloroform fraction of $B$. antidysenterica leaves on mean survival time of mice infected with $P$. berghei in a 4-day suppressive test. $N=6, \mathrm{CON}=$ negative control (solvent $10 \mathrm{ml} / \mathrm{kg}$ ), $\mathrm{CM}=$ crude hydromethanolic extract, $\mathrm{CF}=$ chloroform fraction of $\mathrm{CM}, \mathrm{CQ}=$ chloroquine. a, compared with negative control; b, compared with $100 \mathrm{mg} / \mathrm{kg} ; \mathrm{c}, \mathrm{compared} \mathrm{with}$ $200 \mathrm{mg} / \mathrm{kg}$; d, compared with $400 \mathrm{mg} / \mathrm{kg}$; e, compared with CQ10 mg/kg: 2, $p<0.01 ; 3, p<0.001$.

TABle 3: Percent parasitemia and percent parasitemia inhibition of $P$. berghei-infected mice treated with crude hydromethanolic extract and chloroform fraction of $B$. antidysenterica leaves in the curative test.

\begin{tabular}{|c|c|c|c|c|c|c|}
\hline \multirow[b]{2}{*}{ Extract } & \multirow[b]{2}{*}{ Day 3 \% Para. Supp. } & \multicolumn{4}{|c|}{ Day 5} & \multirow[b]{2}{*}{$\begin{array}{c}\text { Day } 7 \% \text { Para. } \\
\text { Supp. }\end{array}$} \\
\hline & & Day 4 \%Para. Supp. & $\begin{array}{l}\text { Average percent } \\
\text { parasitemia }\end{array}$ & $\begin{array}{l}\text { \%Para. } \\
\text { Supp. }\end{array}$ & Day 6 \%Para. Supp. & \\
\hline CON10 ml/kg & $14.10 \pm 0.54$ & $34.00 \pm 0.83$ & $45.13 \pm 0.48$ & 0.00 & 0.00 & 0.00 \\
\hline CM100 mg/kg & $15.00 \pm 0.37$ & $27.03 \pm 0.81$ & $24.03 \pm 0.68^{\operatorname{acd}(3)}$ & 46.75 & $23.07 \pm 0.42$ & $18.96 \pm 0.78$ \\
\hline CM200 mg/kg & $14.03 \pm 0.60$ & $26.07 \pm 0.46$ & $17.10 \pm 1.05^{\text {abe(3)d } 2}$ & 62.11 & $13.27 \pm 0.31$ & $10.00 \pm 0.47$ \\
\hline $\mathrm{CM} 400 \mathrm{mg} / \mathrm{kg}$ & $15.10 \pm 0.18$ & $29.00 \pm 0.30$ & $13.13 \pm 0.18^{\mathrm{abe}(3) \mathrm{c} 2}$ & 70.90 & $9.07 \pm 2.00$ & $7.50 \pm 0.17$ \\
\hline $\mathrm{CF} 100 \mathrm{mg} / \mathrm{kg}$ & $12.13 \pm 0.20$ & $25.00 \pm 0.24$ & $22.43 \pm 0.95^{\operatorname{acde}(3)}$ & 50.30 & $20.30 \pm 0.60$ & $16.40 \pm 0.54$ \\
\hline $\mathrm{CF} 200 \mathrm{mg} / \mathrm{kg}$ & $14.05 \pm 0.31$ & $20.00 \pm 0.52$ & $15.57 \pm 0.68^{\mathrm{abde}(3)}$ & 65.50 & $11.93 \pm 0.72$ & $9.63 \pm 0.38$ \\
\hline $\mathrm{CF} 400 \mathrm{mg} / \mathrm{kg}$ & $15.13 \pm 0.53$ & $7.07 \pm 0.14$ & $9.00 \pm 0.15^{\text {abce(3) }}$ & 80.06 & $8.70 \pm 0.30$ & $7.30 \pm 0.33$ \\
\hline CQ10 mg/kg & $13.10 \pm 0.38$ & $34.00 \pm 0.83$ & $3.10 \pm 0.22^{\mathrm{abcd}(3)}$ & 93.13 & $0.00 \pm 0.00$ & $0.00 \pm 0.00$ \\
\hline
\end{tabular}

Data are expressed as mean \pm SEM. $n=6$; $\mathrm{CON}=$ negative control; $\mathrm{CM}=$ crude hydromethanolic extract, $\mathrm{CF}=$ chloroform fraction of $B$. antidysenterica; $\mathrm{CQ}=$ chloroquine; \% Para. Supp. = percent parasitemia suppression. a, compared with negative control; b, compared with $100 \mathrm{mg} / \mathrm{kg}$; $\mathrm{c}, \mathrm{compared}$ with $200 \mathrm{mg} / \mathrm{kg} ; \mathrm{d}$, compared with $400 \mathrm{mg} / \mathrm{kg}$; e, compared with CQ10 mg/kg: 2, $p<0.01 ; 3, p<0.001$. 


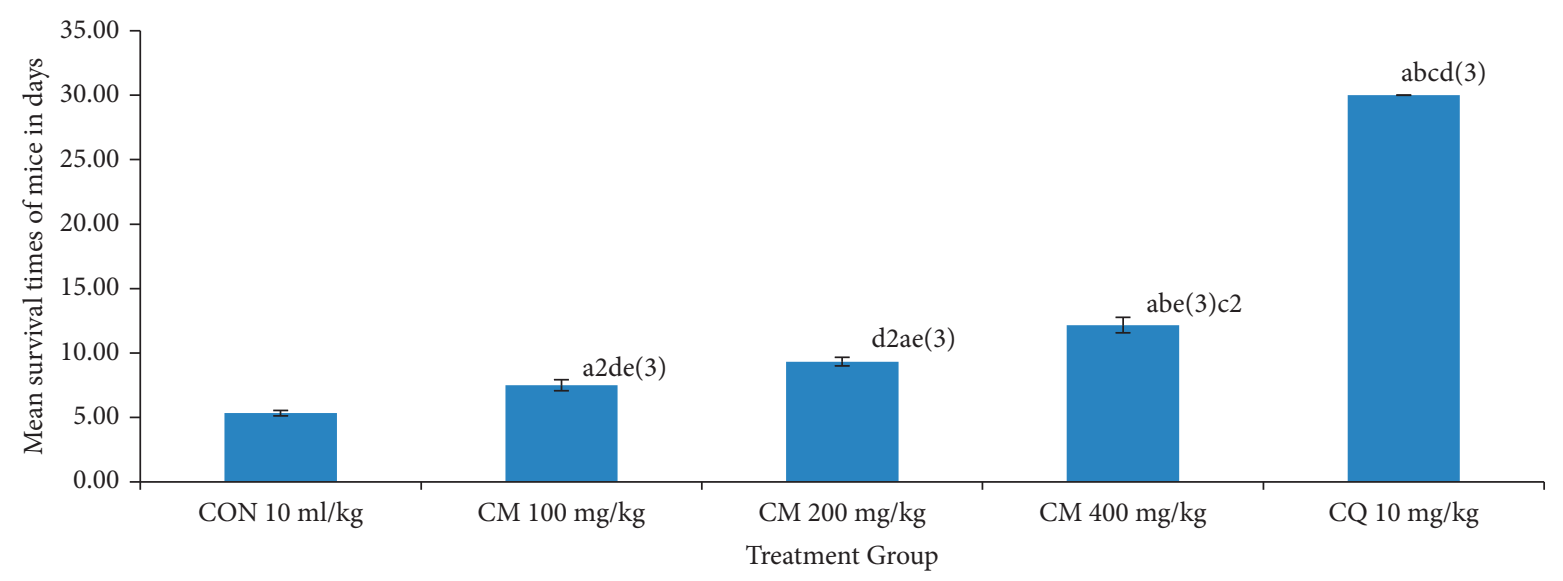

A. CM extract of B. antidysentericaon mean survival of mice in days

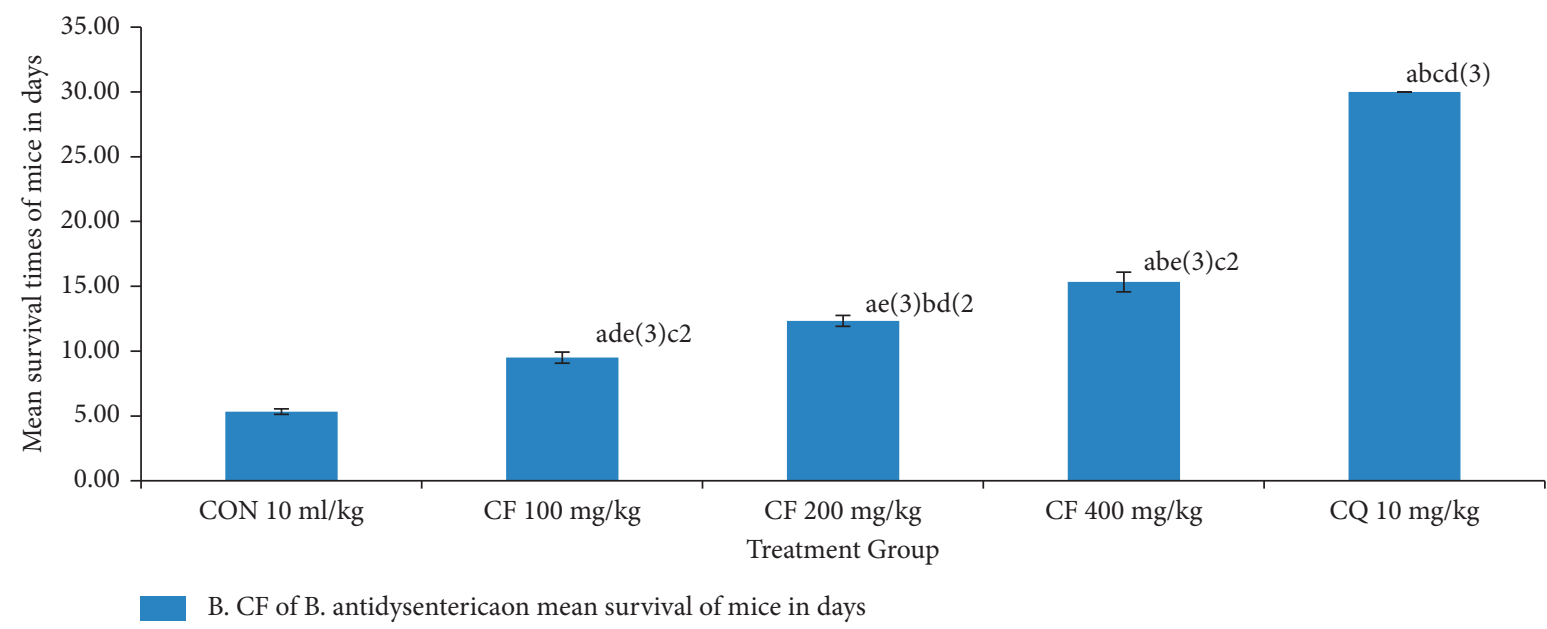

Figure 4: Effects of crude hydromethanolic extract and chloroform fraction of B. antidysenterica leaves on mean survival time of mice infected with $P$. berghei in a suppressive test. $N=6, \mathrm{CON}=$ negative control (solvent $10 \mathrm{ml} / \mathrm{kg}$ ), $\mathrm{CM}=$ crude hydromethanolic extract, $\mathrm{CF}=$ chloroform fraction of $\mathrm{CM}, \mathrm{CQ}=$ chloroquine. a, compared with negative control; b, compared with $100 \mathrm{mg} / \mathrm{kg}$; $\mathrm{c}, \mathrm{compared}$ with $200 \mathrm{mg} / \mathrm{kg}$; d, compared with $400 \mathrm{mg} / \mathrm{kg}$; e, compared with CQ10 mg/kg: 2, $p<0.01 ; 3, p<0.001$.

(57.74\%), Aloe debrana leaves (30.21\%) [14], Carica papaya fruit rinds (17.16\%) and roots (10.15\%) [15], Gardenia ternifolia root bark (32.58\%) [16], Croton macrostachyus leaves (44.00\%) [17], Sphenocentrum jollyanum root (54.15\%) [18], Justicia schimperiana leaves (37.1\%) [19], and Strychnos mitis leaves (36.56\%) [20] and less than Annona senegalensis leaves (59.3\%) [13], Sphenocentrum jollyanum leaves (74.75) [18], Piper betle leaves (70.51\%) [21], Croton zambesicus leaves (80.7\%) [22], and Napoleona imperialis roots (99.1\%) [23]. The crude hydromethanolic extract of $B$. antidysenterica leaves in an exceedingly 4-day suppressive test on mice infected with $P$. berghei at $400 \mathrm{mg} / \mathrm{kg} /$ day showed an average percent parasitemia suppression (75.93\%) higher than Clerodendrum myricoides leaves (65.95\%), Dodonaea angustifolia leaves (71.51), Aloe debrana leaves (44.15\%) [14], Carica papaya fruit rinds (18.39) and roots (25.63\%) [15], Gardenia ternifolia root bark (47.02\%) [16] and less than Annona senegalensis leaves (76.3\%) [13], Croton macrostachyus leaves (78\%) [17], Justicia schimperiana leaves (81.49\%) [19], Piper betle leaves (82.31\%) [21], and Napoleona imperialis roots (96.88\%) [23]. The chloroform fraction of $B$. antidysenterica leaves in an exceedingly 4-day suppressive test on mice infected with $P$. berghei at $100 \mathrm{mg} / \mathrm{kg} /$ day showed an average percent parasitemia suppression (38.32\%) higher than Carica papaya fruit rinds (10.72\%) and roots (9.77) [15] and Strychnos mitis leaves (26.84\%) [20]. The chloroform fraction of B. antidysenterica leaves in a very 4-day suppressive test on mice infected with $P$. berghei at $200 \mathrm{mg} / \mathrm{kg} /$ day showed an average percent parasitemia suppression $(64,49 \%)$ higher than Carica papaya fruit rinds (24.2\%) and roots (25.25) [15], Gardenia ternifolia root bark (24.51\%) [16], Croton macrostachyus leaves (49.4\%) [17], Justicia schimperiana leaves (16.4\%) [19], and Strychnos mitis leaves (31.71\%) [20]. The chloroform fraction of $B$. antidysenterica leaves during a 4-day suppressive test on mice infected with $P$. berghei at $400 \mathrm{mg} / \mathrm{kg} /$ day showed an average percent parasitemia suppression (76.64\%) higher than Carica papaya fruit rinds (37.65\%) and roots (48.11\%) [15], Gardenia ternifolia root bark (31.13\%) [16], Croton macrostachyus leaves (66.2\%) [17], Justicia schimperiana leaves (26.32\%) [19], and Strychnos mitis leaf (39.72\%) [20].

Comparing the results obtained from this study, the crude hydromethanolic extract and chloroform fraction 
showed significant parasitemia inhibition compared with the mice treated with solvent. Extracts that show an adequate or above $50 \%$ proportion of malarial in vivo parasitemia inhibition at doses of 500, 250, and $100 \mathrm{mg} / \mathrm{kg} /$ day are often categorized as moderate, good, and excellent, respectively [12]. Supporting this classification, the hydromethanolic crude extract of B. antidysenterica leaves at 200 and $400 \mathrm{mg} /$ $\mathrm{kg}$ /day showed 58.36 and $75.93 \%$ and chloroform fraction of B. antidysenterica leaves at 200 and $400 \mathrm{mg} / \mathrm{kg} /$ day showed $64.49 \%$ and $76.64 \%$ parasitemia suppression in $P$. bergheiinfected mice, respectively, and therefore considered having good to moderate antiplasmodial activity. A more robust percentage of parasitemia inhibition was observed in chloroform fraction than the crude hydromethanolic extract on the identical doses. The results of our study indicated that the compounds extracted from $B$. antidysenterica leaves which have antimalarial activities were soluble in both hydromethanol and chloroform.

The crude hydromethanolic extract of $B$. antidysenterica leaves at $400 \mathrm{mg} / \mathrm{kg} /$ day prevented percent weight loss significantly compared with mice treated with solvent. The percent weight loss decreased in mice treated with both chloroform fraction and crude hydromethanolic extract from lower to higher doses. An increase in mean body weight was observed in mice treated with chloroquine base as shown in Figure 1. This can be attributed to the reduction in morbidity because of parasite clearance and their normal feeding.

The three different doses of both the chloroform fraction and crude hydromethanolic extract of $B$. antidysenterica leaves showed an increase in the hemoglobin level compared with mice treated with the solvent, but at doses 100 and $200 \mathrm{mg} / \mathrm{kg} /$ day did not produce a major difference compared with the mice treated with solvent. The mice treated with crude hydromethanolic extract have a lower mean hemoglobin level than mice treated with similar doses of chloroform fraction. The noninfected mice were compared with the treatment group as a customary since earlier peerreviewed journals used the packed cell volume to gauge anemia associated with P. berghei infection [51]. We used hemoglobin measurements that needed low volume of blood and were easy to research instrumentally in a quick time and compared the packed cell volume between groups.

The three different doses of both the chloroform fraction and crude hydromethanolic extract of B. antidysenterica leaves showed an increase in mean survival time compared with mice treated with the solvent, but crude hydromethanolic extract at doses of 100 and $200 \mathrm{mg} / \mathrm{kg} /$ day did not produce a major difference compared with the mice treated with solvent. Chloroform fraction at doses of 200 and $400 \mathrm{mg} / \mathrm{kg} /$ day showed a significant increase in mean survival time compared with the mice treated with solvent. Significant difference of antimalarial activity was observed in chloroquine-treated mice compared with the mice treated with solvent.

In the curative test, the percent parasitemia level increased from 72 hours to 120 hours in the negative control, and ultimately, all the infected mice died before the sixth day sample was collected. Mice infected with $P$. berghei treated with crude hydromethanolic extract and chloroform fraction of $B$. antidysenterica leaves showed an increase in the percent parasitemia level from day 3 up to day 4 and showed a decrease in percent parasitemia level from day 5 up to day 7 in a dose-dependent manner compared with the mice treated with solvent. The infected mice treated with chloroquine base showed a decrease in average percent parasitemia from 72 hours to 120 hours, and the parasitemia was completely cleared on the $6^{\text {th }}$ and $7^{\text {th }}$ day of treatment.

The promising result from Rane's study suggests that the crude hydromethanolic extract and chloroform fraction of $B$. antidysenterica leaves have therapeutic efficacies against established malarial parasitic infections.

\section{Conclusion}

From this research, we came across a judgment that crude hydromethanolic extract and chloroform fraction of B. antidysenterica leaves have shown promising antiplasmodial activity in $P$. berghei-infected mice, which supports its traditional medicine use. Thus, it may be believed to be a possible source to formulate new antimalarial medications; however, these results cannot be applied on to humans due to species variation.

\section{Recommendation}

This research investigated that the plant $B$. antidysenterica leaves have therapeutic values in malarial infections. So, advanced comprehensive studies in $P$. falciparum infection using other appropriate models are needed and justifiable.

Brucea antidysenterica is a multipurpose wild plant used for the building of homes, firewood, animal feed, and treatment of various diseases both in humans and other animals that the concerned bodies are advised to require measures to conserve it.

\section{Abbreviations}

CQ: Chloroquine

EPHI: Ethiopian Public Health Institute

$\mathrm{IC}_{50}$ : $50 \%$ inhibitory concentration

$\mathrm{LD}_{50}$ : Median lethal dose 50

PRBCs: Parasitized red blood cells

RBCs: Red blood cells.

\section{Data Availability}

The data sets used and/or analyzed during the current study are available from the corresponding author and will be delivered to responsible bodies on reasonable request.

\section{Ethical Approval}

The animals were handled in line with the governance of Animal Care and Use for Scientific Purposes in Africa and then the nation state [33]. Ethical clearance was requested and obtained from the Institutional Review Board of Debre Tabor University with a permission letter Ref. No: DU/RPD/ 
$102 / 2015$, and also the research was performed as per the agreement.

\section{Conflicts of Interest}

The authors declare that they have no competing interest to disclose.

\section{Authors' Contributions}

Both the authors made fundamental benefactions, formulation, elegance, and acquisition of data or investigation and explanation of data; took part in sketching the article or reappraising it critically for important intellectual content; agreed to submit this journal; gave final approval of the version to be published; and agreed to be accountable of all aspects of the work.

\section{Acknowledgments}

The authors are very grateful to Debre Tabor University for the approval of ethical clearance and other technical supports. Second, the authors would value more highly to thank the University of Gondar for support of laboratory facility and authentication of experimental plant. Lastly, the authors thank the Ethiopian Public Health Institute (EPHI) for nocost delivery of $P$. berghei parasites.

\section{References}

[1] M. Ren, "Greater political commitment needed to eliminate malaria," Infectious Diseases of Poverty, vol. 8, no. 1, pp. 28-34, 2019.

[2] T. K. Hartman, S. J. Rogerson, and P. R. Fischer, "The impact of maternal malaria on newborns," Annals of Tropical Paediatrics, vol. 30, no. 4, pp. 271-282, 2010.

[3] World Health Organization, World Malaria Report 2015, Geneva, Switzerland, 2016, https://scholar.google.com/scholar?hl=en\&as_ $\mathrm{sdt}=0 \% 2 \mathrm{C} 5 \& \mathrm{q}=$ Sheet + WF. + World + Malaria + Report +2015 . +Geneva\%3A+World+Health+Organization.+2016\&btnG=.

[4] A. Enayati and J. Hemingway, "Malaria management: past, present, and future," Annual Review of Entomology, vol. 55, no. 1, pp. 569-591, 2010.

[5] A. Adugna, "Malaria in Ethiopia, lesson 14," 2020, https:// scholar.google.com/scholar?hl=en\&as_sdt=0\%2C5\&q=Adugna + A. + Malaria+in+Ethiopia\%2C+lesson+14\&btnG=.

[6] A. Deribew, T. Dejene, B. Kebede et al., "Incidence, prevalence and mortality rates of malaria in Ethiopia from 1990 to 2015: analysis of the global burden of diseases 2015," Malaria Journal, vol. 16, no. 1, pp. 271-277, 2017.

[7] D. N. Ogbonna, T. G. Sokari, and A. A. Agomuoh, "Antimalarial activities of some selected traditional herbs from south eastern Nigeria against Plasmodium species," Research Journal of Parasitology, vol. 3, no. 1, pp. 25-31, 2008.

[8] Z. Petros, "The need of standardized herbal remedies as alternate sources of antimalarial products in Ethiopia-updated review," Pharmacologyonline, vol. 3, pp. 1440-1447, 2011.

[9] D. A. Fidock, P. J. Rosenthal, S. L. Croft, R. Brun, and S. Nwaka, "Antimalarial drug discovery: efficacy models for compound screening," Nature Reviews Drug Discovery, vol. 3, no. 6, pp. 509-520, 2004.
[10] B. Kalra, S. Chawla, P. Gupta, and N. Valecha, "Screening of antimalarial drugs: an overview," Indian Journal of Pharmacology, vol. 38, no. 1, pp. 5-12, 2006.

[11] A. Krettli, J. Adebayo, and L. Krettli, "Testing of natural products and synthetic molecules aiming at new antimalarials," Current Drug Targets, vol. 10, no. 3, pp. 261-270, 2009.

[12] M. Eyasu, W. Shibeshi, and M. Giday, "In vivo antimalarial activity of hydromethanolic leaf extract of Calpurnia aurea (Fabaceae) in Mice infected with chloroquine sensitive Plasmodium berghei," International Journal of Pharmacology, vol. 2, pp. 131-142, 2013.

[13] E. Ajaiyeoba, M. Falade, O. Ogbole, L. Okpako, and D. Akinboye, "In vivo antimalarial and cytotoxic properties of Annona senegalensis extract," African Journal of Traditional, Complementary and Alternative Medicines, vol. 3, no. 1, pp. 137-141, 2006.

[14] T. Deressa, Y. Mekonnen, and A. Animut, "Vivo anti-malarial activities of Clerodendrum myricoides, Dodonea angustifolia and Aloe debrana against Plasmodium berghei," The Ethiopian Journal of Health Development, vol. 24, no. 1, 2010.

[15] G. Zeleke, D. Kebebe, E. Mulisa, and F. Gashe, "In vivo antimalarial activity of the solvent fractions of fruit rind and root of Carica papaya Linn (Caricaceae) against Plasmodium berghei in mice," Journal of Parasitology Research, vol. 2017, Article ID 3121050, 9 pages, 2017.

[16] D. Nureye, S. Assefa, T. Nedi, and E. Engidawork, "In vivo antimalarial activity of the 80 Methanolic root bark extract and solvent fractions of Gardenia ternifolia Schumach. \& Thonn.(Rubiaceae) against Plasmodium berghei," EvidenceBased Complementary and Alternative Medicine, vol. 2018, Article ID 9217835, 10 pages, 2018.

[17] L. Bantie, S. Assefa, T. Teklehaimanot, and E. Engidawork, "In vivo antimalarial activity of the crude leaf extract and solvent fractions of Croton macrostachyus Hocsht. (Euphorbiaceae) against Plasmodium berghei in mice," BMC Complementary and Alternative Medicine, vol. 14, no. 1, p. 79, 2014.

[18] S. Olorunnisola and A. J. Afolayan, "In vivo anti-malaria activity of methanolic leaf and root extracts of Sphenocentrum jollyanum Pierre," African journal of pharmacy and pharmacology, vol. 5, no. 14, pp. 1669-1673, 2011.

[19] J. Abdela, E. Engidawork, and W. Shibeshi, "In vivo antimalarial activity of solvent fractions of the leaves of justicia schimperiana hochst. Ex Nees against Plasmodium berghei in Mice," Ethiopian Pharmaceutical Journal, vol. 30, no. 2, pp. 95-108, 2014.

[20] S. Fentahun, E. Makonnen, T. Awas, and M. Giday, "In vivo antimalarial activity of crude extracts and solvent fractions of leaves of Strychnos mitis in Plasmodium berghei infected mice," BMC Complementary and Alternative Medicine, vol. 17, no. 1, p. 13, 2017.

[21] A. H. Al-Adhroey, Z. M. Nor, H. M. Al-Mekhlafi, A. A. Amran, and R. Mahmud, "Antimalarial activity of methanolic leaf extract of Piper betle L," Molecules, vol. 16, no. 1, pp. 107-118, 2011.

[22] J. Okokon, K. Ofodum, K. Ajibesin, B. Danladi, and K. Gamaniel, "Pharmacological screening and evaluation of antiplasmodial activity of Croton zambesicus against Plasmodium berghei berghei infection in mice," Indian Journal of Pharmacology, vol. 37, no. 4, p. 243, 2005.

[23] I. H. Ogbuehi, O. O. Ebong, E. O. Asuquo, and C. A. Nwauche, "Evaluation of the anti-plasmodial activity of the methanolic root extracts of anthocleista nobilis G. Don, nauclea latifolia smith and Napoleona imperialis P. Beauv," British Journal of Pharmacology and Toxicology, vol. 5, no. 2, pp. 75-82, 2014. 
[24] O. M. Grace, Brucea Antidysenterica JF Mill. Medicinal Plants/ Plantes Médicinales, PROTA, Wageningen, Netherlands, 2008.

[25] H. Reta, S. Demissew, and Z. Asfaw, "Plant diversity study on Kelekal protected forest in Debre Markos town district, East Gojjam, Amhara region, Ethiopia," Sustainability in Environment, vol. 4, 2019.

[26] D. Abebe and E. Hagos, "Plants as a primary source of drugs in the traditional health practices of Ethiopia," Plant Genetic Resources of Ethiopia, pp. 101-113, 1991.

[27] A. Geyid, D. Abebe, A. Debella et al., "Screening of some medicinal plants of Ethiopia for their anti-microbial properties and chemical profiles," Journal of Ethnopharmacology, vol. 97, no. 3, pp. 421-427, 2005.

[28] C. Ramalhete, D. Lopes, S. Mulhovo, V. E. Rosário, and M. J. Ferreira, "Antimalarial activity of some plants traditionally used in Mozambique," InWorkshop Plantas Medicinais e Fitoterapêuticas nos Trópicos. IICT/CCCM, vol. 29, p. 30, 2008.

[29] S. M. Kupchan, R. W. Britton, J. A. Lacadie, M. F. Ziegler, and C. W. Sigel, "Tumor inhibitors. 100. Isolation and structural elucidation of bruceantin and bruceantinol, new potent antileukemic quassinoids from Brucea antidysenterica," Journal of Organic Chemistry, vol. 40, no. 5, pp. 648-654, 1975.

[30] M. Cuendet and J. M. Pezzuto, "Antitumor activity of bruceantin: an old drug with new Promise $\$, \perp$," Journal of Natural Products, vol. 67, no. 2, pp. 269-272, 2004.

[31] F. D. Gillin, D. S. Reiner, and M. Suffness, "Bruceantin, a potent amoebicide from a plant, Brucea antidysenterica," Antimicrobial Agents and Chemotherapy, vol. 22, no. 2, pp. 342-345, 1982.

[32] M. J. O’Neill, D. H. Bray, P. Boardman et al., "Plants as sources of antimalarial drugs: in vitro antimalarial activities of some quassinoids," Antimicrobial Agents and Chemotherapy, vol. 30, no. 1, pp. 101-104, 1986.

[33] L. H. Carvalho, M. G. Brandão, D. Santos-Filho, J. L. Lopes, and A. U. Krettli, "Antimalarial activity of crude extracts from Brazilian plants studied in vivo in Plasmodium berghei-infected mice and in vitro against Plasmodium falciparum in culture," Brazilian Journal of Medical and Biological Research, vol. 24, no. 11, pp. 1113-1123, 1991.

[34] A. A. Alehegn, J. S. Yesuf, and E. M. Birru, "Antimalarial activity of crude extract and solvent fractions of the leaves of Bersama abyssinica fresen. (Melianthaceae) against Plasmodium berghei infection in Swiss albino mice," Evidence-Based Complementary and Alternative Medicine, vol. 2020, Article ID 9467359, 14 pages, 2020.

[35] T. J. Aragaw, D. T. Afework, and K. A. Getahun, “Antimalarial activities of hydromethanolic crude extract and chloroform fraction of Gardenia ternifolia leaves in Plasmodium berghei infected mice," Evidence-Based Complementary and Alternative Medicine, vol. 2020, Article ID 6674002, 11 pages, 2020.

[36] M. A. Alemayehu, M. Abdelwuhab, and D. A. Gelayee, "Invivo anti-malarial activity of crude extract and solvent fractions of the roots of clematis simensis fresen. (Ranunculaceae) in plasmodium berghei infected mice," IOSR Journal of Pharmacy and Biological Sciences, vol. 14, 2019.

[37] S. F. Zohra, B. Meriem, S. Samira, and M. A. Muneer, "Phytochemical screening and identification of some compounds from mallow," Journal of Natural Product and Plant Resources, vol. 2, no. 4, pp. 512-516, 2012.
[38] F. Alafid, S. M. Edrah, F. M. Meelad, S. Belhaj, K. Altwair, and N. R. Maizah, "Evaluation of phytochemical constituents and antibacterial activity of thymelaea hirsuta (1.) Endl, and that utilised as a conventional treatment of infertility and diabetic in Libya," World Journal of Pharmaceutical Research, vol. 8, no. 11, pp. 72-88, 2019.

[39] A. Scalbert, "Antimicrobial properties of tannins," Phytochemistry, vol. 30, no. 12, pp. 3875-3883, 1991.

[40] H. Usman, F. Abdulrahman, and A. Usman, "Qualitative phytochemical screening and in vitro antimicrobial effects of methanol stem bark extract of Ficus thonningii (Moraceae)," African Journal of Traditional, Complementary, and Alternative Medicines: AJTCAM, vol. 6, no. 3, pp. 289-95, 2009.

[41] C. O. Ochieng, J. O. Midiwo, and P. O. Owuor, "Anti-plasmodial and larvicidal effects of surface exudates of gardenia ternifolia aerial parts," Research Journal of Pharmacology, vol. 4, 2010.

[42] T. Ozcan, A. Akpinar-Bayizit, L. Yilmaz-Ersan, and B. Delikanli, "Phenolics in human health," International Journal of chemical engineering and applications, vol. 5, no. 5, pp. 393-396, 2014.

[43] M. M. Cowan, "Plant products as antimicrobial agents," Clinical Microbiology Reviews, vol. 12, no. 4, pp. 564-582, 1999.

[44] D. U. Marie-Esther, O. C. Concilia, U. Chioma, K. F. Chimaobi, and O. Austin, "In vivo antimalarial and cytotoxicity activity of ethanolic stem bark of Petersianthus macrocarpus and leaf of Astonia boonei in experimental mice model," International Journal of Current Microbiology and Applied Sciences, vol. 2, no. 12, pp. 354-368, 2013.

[45] L. Othman, A. Sleiman, and R. M. Abdel-Massih, "Antimicrobial activity of polyphenols and alkaloids in middle eastern plants," Frontiers in Microbiology, vol. 10, p. 911, 2019.

[46] C. Omojate Godstime, O. Enwa Felix, O. Jewo Augustina, and O. Eze Christopher, "Mechanisms of antimicrobial actions of phytochemicals against enteric pathogens-a review," Journal of Pharmaceutical, Chemical and Biological Sciences, vol. 2, no. 2, pp. 77-85, 2014.

[47] S. Gollapudi, H. A. Sharma, S. Aggarwal, L. D. Byers, H. E. Ensley, and S. Gupta, "Isolation of a previously unidentified polysaccharide (MAR-10) from Hyssop officinalis that exhibits strong activity against human immunodeficiency virus type 1," Biochemical and Biophysical Research Communications, vol. 210, no. 1, pp. 145-151, 1995.

[48] Organization for Economic Co-operation and Development, Test No. 425: Acute Oral Toxicity: Up-And-Down Procedure, OECD Publishing, Paris, France, 2008.

[49] B. J. Mohr, F. A. Fakoya, J. Hau, O. Souilem, and L. Anestidou, "The governance of animal care and use for scientific purposes in Africa and the Middle East," ILAR Journal, vol. 57, no. 3, pp. 333-346, 2016.

[50] S. Parasuraman, "Toxicological screening," Journal of Pharmacology and Pharmacotherapeutics, vol. 2, no. 2, pp. 74-79, 2011.

[51] D. A. Fidock, P. J. Rosenthal, S. L. Croft, R. Brun, and S. Nwaka, "Antimalarial drug discovery: efficacy models for compound screening. Supplementary documents," Trends in Parasitology, vol. 15, pp. 19-29, 2004.

[52] O. A. Iyiola, A. Y. Tijani, and K. M. Lateef, "Antimalarial activity of ethanolic stem bark extract of Alstonia boonei in mice," Asian Journal of Biological Sciences, vol. 4, no. 3, pp. 235-243, 2011. 
[53] A. I. Rappaport, C. D. Karakochuk, K. C. Whitfield, K. M. Kheang, and T. J. Green, "A method comparison study between two hemoglobinometer models (Hemocue Hb 301 and $\mathrm{Hb} 201+$ ) to measure hemoglobin concentrations and estimate anemia prevalence among women in Preah Vihear, Cambodia," The International Journal of Literary Humanities, vol. 39, no. 1, pp. 95-100, 2017.

[54] J. O. Kokwaro, Medicinal Plants of East Africa, pp. 176-177, Kenya Literature Bureau, Nairobi, Kenya, 1993. 